\title{
Urban myths exploded: results of a bryological survey of King's Lynn (Norfolk, UK)
}

\author{
C. ROBIN STEVENSON ${ }^{1}$ and MARK O. HILL ${ }^{2}$ \\ ${ }^{1}$ King's Lynn and ${ }^{2}$ Centre for Ecology and Hydrology, Monks Wood, U.K.
}

\begin{abstract}
SUMMARY
Generalizations about urban bryophytes in European cities have received little attention in Britain. Here they are treated as hypotheses, to be tested against the results of a detailed survey of King's Lynn, a town of about 41000 people in eastern England. During 1999-2004 the flora was enumerated in twenty-five 1-km squares, arranged in a square of side $5 \mathrm{~km}$. The species total for King's Lynn was 151, with an average of 42 species per $1-\mathrm{km}$ square. We compared the flora of the town with that of the East Anglian region, from which 345 species have been recorded. Frequency of species in 1-km squares of King's Lynn was strongly related to frequency in 5-km squares in East Anglia. The King's Lynn flora was, for the region, exceptionally species-rich, with more calcifuges and fewer epiphytes than would be expected from the regional average. In the $1-\mathrm{km}$ square containing the town centre, 28 species were recorded, of which Bryum caespiticium, Ceratodon purpureus, Funaria hygrometrica and Marchantia polymorpha were more frequent in the town than in the wider countryside.
\end{abstract}

KEYWORDS: Biogeography, bryophyte attributes, East Anglia, Ellenberg values, floristics.

\section{INTRODUCTION}

Urban areas are difficult to define, and there is no general agreement amongst geographers; criteria employed include function, structure and population size. The UNESCO (1973) definition, i.e. any settlement with a population of over 20000 , is that adopted here. Such settlements range from vast industrial agglomerations, with or without satanic mills, through to small market towns in rural settings. However, they are all dynamic entities, responding to social and economic pressures and to the changing whims and fashions of planners and politicians. Nonetheless, certain fundamental land use types are common to most urban areas in the developed world and some of these (e.g. city centre; suburban; industrial; recreational, etc.) have been used as recording units in studies of urban bryophytes.

In terms of habitat diversity for bryophytes, towns all have one thing in common - an abundance of 'rock' surfaces open for colonisation, be they brick, concrete or stone. They may also possess water bodies, parks, gardens, and areas of woodland which may offer more 'natural' habitats. All of these will, however, be influenced by local geology, soils, climate, and the existence - whether

(C) British Bryological Society 2008 DOI: $10.1179 / 174328208 X 282111$ currently or formerly - of pollution. Urban areas can, therefore, offer either diversity or poverty of habitat.

Although the majority of bryologists in Britain probably live in urban areas there are few accounts of urban bryophytes in the U.K., except those by Gilbert (1968, 1971). These studies, conducted in Newcastle-upon-Tyne, established that the bryofloras at that period were greatly affected by $\mathrm{SO}_{2}$. Gilbert was able to demonstrate that different bryophyte communities could be correlated with accurately determined levels of $\mathrm{SO}_{2}$. He established two principles: (1) that as pollution levels increased, the diversity of the bryoflora on the substrates he had specified in his study decreased; and (2) that specific bryophytes could be used as indicators of particular levels of pollution.

At the time of Gilbert's work there was much interest in bio-monitoring, and numerous other studies confirmed the principle that pollution had an adverse effect on bryophytes. Burton (1990) provides a summary of information on the topic. Subsequently, bryophyte populations have shown considerable signs of recovery as a result of reduced atmospheric pollution (Bates, Bell \& Farmer, 1990; Adams \& Preston, 1992).

There have been many studies of urban bryophytes in Europe, e.g. Schaepe (1986); Carcano (1989); Cortini 
Pedrotti (1989); Lo Giudice (1992); Fudali (1994, 1996, 1998); Vanderpoorten (1997). From these, some generalizations regarding urban bryofloras have been proposed (Table 1). A recent survey of the bryophytes of King's Lynn has been used to test them.

\section{LOCATION OF STUdY}

\section{Site and situation}

King's Lynn is a market town in eastern England. It is situated on the eastern bank of the River Great Ouse, $4 \mathrm{~km}$ inland from the Wash (Fig. 1). The Gaywood river and water from the Middleton Stop Drain both flow through the town, though their courses have been much altered and integrated with a complex pattern of internal drainage channels. The river Nar at one time formed the southern boundary of the town. To the north, the land is largely arable and consists of reclaimed salt marsh. The site is lowlying with little topographic variation; in the northwest of the study area the ground rises to a maximum height of $35 \mathrm{~m}$ before dropping into the Gaywood valley, which is separated from the low ground associated with the Middleton Stop Drain by a slight ridge. A satellite settlement, West Lynn, lies on the opposite bank of the Great Ouse.

\section{Climate, geology and soils}

King's Lynn, in common with the rest of East Anglia, has a temperate oceanic climate. January and July mean temperatures are 3.3 and $16.0^{\circ} \mathrm{C}$; annual precipitation is $620 \mathrm{~mm}$ (Barrow, Hulme \& Jiang, 1993).

The soils in the lower lying parts of the town are based on silts and clays of marine and alluvial origin. The ground rises to the east, where the underlying rocks are acidic lower Cretaceous sands. However this simple picture is complicated by the presence of calcareous tills ('chalky boulder clay' of Anglian [Elsterian] age), and fluvio-glacial sands in places; organic peat soils are locally present in the Gaywood valley. As a result, soil conditions can vary quite widely, even over short distances.

Gilbert (1989) describes the characteristics of urban soils. Man-made and top-soiled sites exist mainly in gardens, allotments and public open spaces, such as parks. However, the practice of putting down top-soil in gardens is relatively recent; in older gardens the soil is that which was available on site. Raw lithomorphic soils of various types also occur, though sparingly. In waste areas brick rubble may occur; basic furnace slag is mainly found along railway lines, along with ballast made from acid igneous rocks. Chemical wastes are found at a former industrial site in South Lynn, whilst subsoils are exposed on steep banks such as the sides of dykes. Hard surfaces, such as tarmac, paved areas, roads and concrete, are widely present.

\section{History}

During medieval times King's Lynn was an important port. It then went into a period of relative decline, and only began to expand again slowly during the 18th and 19th centuries. In the 1930s ribbon development began to take

Table 1. The main generalisations made regarding the nature of urban bryofloras.

\begin{tabular}{|c|c|c|}
\hline Hypotheses about urban bryofloras & Tests & References \\
\hline $\begin{array}{l}\text { 1. Impoverishment. They are } \\
\text { impoverished, due to air pollution, } \\
\text { and/or habitat destruction. }\end{array}$ & $\begin{array}{l}\text { Compare species richness with that of } \\
\text { comparable non-urbanized areas. }\end{array}$ & $\begin{array}{l}\text { Lara, López \& Mazimpaka (1991); Lo Giudice } \\
\text { (1992); Soria \& Ron (1995); Lo Giudice, Mazimpaka } \\
\text { \& Lara (1997); Vanderpoorten (1997). }\end{array}$ \\
\hline $\begin{array}{l}\text { 2. Distinctive nature. There are distinctive } \\
\text { urban bryofloras. }\end{array}$ & $\begin{array}{l}\text { Find out whether some species are more } \\
\text { frequent in urban areas than elsewhere; } \\
\text { test whether the environmental profiles of } \\
\text { urban species are similar to those of } \\
\text { the region outside the town. }\end{array}$ & $\begin{array}{l}\text { Lara et al. (1991); Soria \& Ron (1995); } \\
\text { Fudali }(1998,2000) \text {. }\end{array}$ \\
\hline 3. Toxitolerance. They are toxitolerant. & $\begin{array}{l}\text { Compare profile of toxitolerant species with } \\
\text { that of comparable non-urbanized areas. }\end{array}$ & $\begin{array}{l}\text { Ballesteros Segura \& Ron (1985); Lo } \\
\text { Giudice (1992); Soria \& Ron (1995); } \\
\text { Lo Giudice et al. (1997). }\end{array}$ \\
\hline $\begin{array}{l}\text { 4. Life strategies. Certain life strategies, } \\
\text { notably 'colonists', are favoured. }\end{array}$ & Compare profile of life strategies. & $\begin{array}{l}\text { Ron et al. (1987); Heras \& Soria (1990); } \\
\text { Soria \& Ron (1995). }\end{array}$ \\
\hline 5. Life-forms. Certain life-forms are favoured. & Compare profile of life-forms. & $\begin{array}{l}\text { Cortini Pedrotti (1989); Lara et al. (1991); } \\
\text { Soria \& Ron (1995); Lo Giudice et al. (1997). }\end{array}$ \\
\hline $\begin{array}{l}\text { 6. Family bias. Certain families are better } \\
\text { adapted to urban conditions than others, } \\
\text { notably the Pottiaceae. }\end{array}$ & Compare profile of families. & $\begin{array}{l}\text { Lara et al. (1991); Lo Giudice (1992); } \\
\text { Lo Giudice et al. (1997). }\end{array}$ \\
\hline $\begin{array}{l}\text { 7. Phytogeography. There is a bias towards } \\
\text { more thermophilic species. }\end{array}$ & Compare profile of temperature preferences. & Lara et al. (1991); Lo Giudice (1992). \\
\hline $\begin{array}{l}\text { 8. Vitality. Vitality is reduced, reducing } \\
\text { sporophyte production and increasing } \\
\text { reliance on vegetative reproduction. }\end{array}$ & $\begin{array}{l}\text { Not testable without ecological data; it } \\
\text { would be necessary to compare comparable } \\
\text { habitats or make transplant experiments. }\end{array}$ & $\begin{array}{l}\text { Cortini Pedrotti (1989); Heras \& Soria (1990); } \\
\text { Lara et al. (1991); Soria \& Ron (1995); } \\
\text { Lo Giudice et al. (1997); Hohenwallner \& } \\
\text { Zechmeister (2001). }\end{array}$ \\
\hline
\end{tabular}




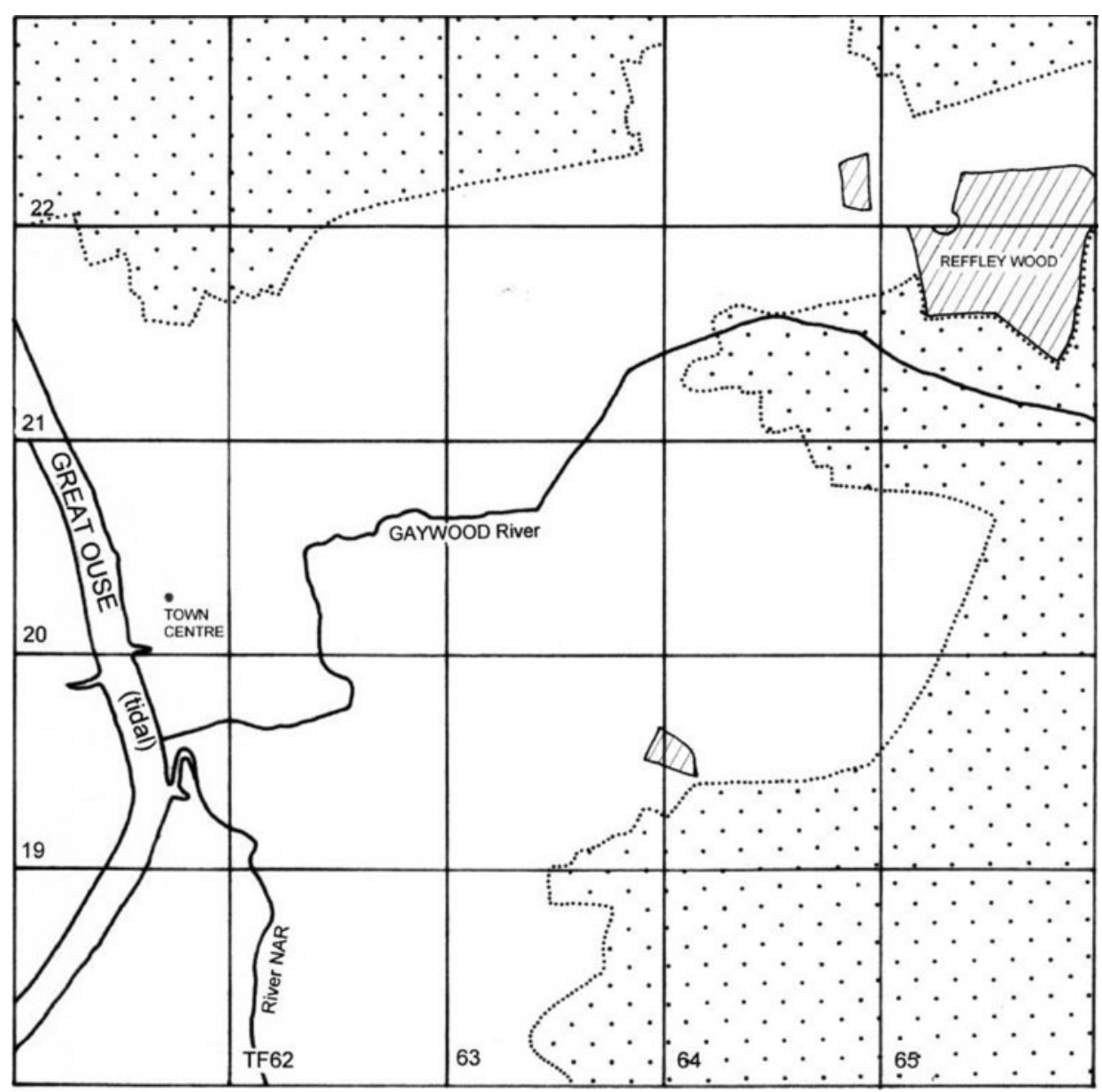

Figure 1. King's Lynn, showing rivers and selected landcover types, including ancient woodland (hatched) and unwooded rural land (stippled); the grid lines are spaced at intervals of $1 \mathrm{~km}$.

place alongside major routes out of the town. Large-scale expansion occurred during the 1950s and 1960s, when Lynn acted as an 'overspill' town, attracting many newcomers from London. Modern housing estates, both private and public, were built, usually encroaching onto previously agricultural or rural land. Several relics of older land uses such as orchards survive as small enclaves of waste/derelict land. At the time of the national census of 2001, the town had a population of 41000 .

\section{Bryophyte recording}

There are no previous accounts of the bryology of King's Lynn. Published records covering the whole of Norfolk (Petch \& Swann, 1968; Swann, 1975, 1982; Beckett, Bull \& Stevenson 1999) make occasional reference to King's Lynn and environs, but lack precise details of localities. These sources have therefore been ignored. Nor has any attempt been made to trace records in local or national herbaria as they are unlikely to contain many species from the town. Payne (1995) has published an account of the vascular plants of the town, though he limited his study to plants found within the boundaries of the former medieval town.

\section{Regional data for comparison}

To test hypotheses about urban bryophytes, we needed a control dataset from non-urban sites in the vicinity. No other data had been collected in East Anglia at 1-km resolution, but we had access to two substantial datasets, one collected at $5-\mathrm{km}$ resolution and the other with partial coverage at $2-\mathrm{km}$ resolution. A third, small dataset was at $10-\mathrm{km}$ resolution. This consisted of species lists for the grid squares TF50, TF51, TF52, TF60, TF63, TF64, TF70, TF71, TF72, TF73 and TF74, which are very close to King's Lynn but do not include the study area. The dataset at 5-km resolution is for Cambridgeshire, which has been resurveyed since 2000 by the Cambridgeshire Bryological Recording Group. In total, 89 squares have at least 50\% of their area in the vice-county of Cambridgeshire, which comprises the administrative districts of South Cambridgeshire and the Isle of Ely. The $5-\mathrm{km}$ squares were divided into 'North Cambs', the 44 squares north of the Ordnance Survey northing 270 000, and 'South Cambs', the 45 squares south of it.

The other large regional dataset was from Suffolk, the East Anglian county south of Norfolk. This had been surveyed in 2-km squares ('tetrads') by Richard Fisk. To 
get a dataset with similar resolution to that from Cambridgeshire, records were amalgamated from the six surveyed tetrads nearest the southwestern corner of each $10-\mathrm{km}$ square ('hectads'). These made up a total of $24 \mathrm{~km}^{2}$, which is very similar to the $25 \mathrm{~km}^{2}$ recorded in Cambridgeshire. (A check was made to find out whether species totals from hectads where the tetrads were concentrated in the southwestern corner were smaller than totals from hectads where the tetrads were more widely scattered. No difference was found, so the sample was taken to be homogeneous.)

\section{Methodology}

\section{Survey methodology}

Twenty-five of the 1-km squares of the British National Grid, arranged in a $5 \times 5 \mathrm{~km}$ block, were used as a basis for recording. This choice was based on convenience. The main purposes were to document the bryophytes of an urban area and to establish a baseline against which future changes might be measured. Extending the survey beyond these limits was not deemed necessary, even though parts of the town do lie outside the study area. (The characteristics of the squares used, and their co-ordinates, are tabulated in supplementary material.)

Some of the squares used in the survey are wholly urban; some are almost wholly agricultural. Many show intermediate characteristics: urban parks and waste land may provide semi-natural habitats, even in the heart of town. The reason why the suburbs and surrounding fringes have been recorded is that these are the areas which will probably show the greatest changes in future, as Lynn expands and land use changes. It may be their fate to become fragments of 'encapsulated countryside'.

Each square was visited on a number of occasions, depending on the number of habitats present. Squares with complex land uses (for example woodland, industrial and residential areas) took longer to record than purely arable areas. Surveying was repeated until no new species were being found. Some habitats such as gardens or roofs, which are difficult of access, were sampled less rigorously than others.

Initially recording was based on a series of land use types and habitats within them, until it was realised that the system was unnecessarily complicated. A bryophyte is not going to differentiate between a school playing field, a garden lawn and the greensward in a park. Similarly, a brick, stone, or concrete wall is much the same, whether it is holding up a house, a factory, or merely acting as a property divide.

For the analysis, 1-km squares were classified in three types, urban, mixed and rural. These categories, originally defined from maps, were compared with the Land Cover Map of Great Britain (LCMGB), based on satellite images (Fuller, Groom \& Jones, 1994). The Land Cover
Map recognizes two predominantly urban categories, urban and suburban. These were added together to obtain a combined urban cover. Squares classified as urban had at least $40 \%$ combined urban land cover. Mixed squares had $20-39 \%$ combined urban land cover, and rural squares had $0-19 \%$.

\section{Bryophyte attributes}

Species attributes, including taxonomic order, frequency in Great Britain (out of 2789 hectads with at least 1 ha of land), climatic preferences, habitat indicator values, substrate preferences, life form and life history, were taken from BRYOATT (Hill et al., 2007). Habitat indicator values include 'Ellenberg values' for Light $(L)$, Moisture $(M)$, Reaction $(R)$, Nitrogen $(N)$ and Salt $(S)$, together with a newly-compiled indicator of heavy-metal tolerance. Substrate preferences were used to produce a list of 'obligate epiphytes' - species restricted to wood as a substrate. This included four species for which hard rock is also indicated as a substrate in BRYOATT. As hard rock (as opposed to worked rock, including brickwork, slates and masonry) is almost totally unavailable as a substrate in East Anglia, we have treated these species as obligate epiphytes in the region. Annuality is defined as 0 for a perennial, 100 for an annual, and 33 and 67 for the two intermediate categories.

\section{Statistical analysis}

Frequencies of occurrence in the $251-\mathrm{km}$ squares of King's Lynn were related to those in the $1465-\mathrm{km}$ squares of the East Anglian region by means of logistic regression. Specifically, let

$$
\begin{aligned}
& x=\text { number of occurrences out of } 146 \text { in the region } \\
& y=\text { number of occurrences out of } 25 \text { in King's Lynn }
\end{aligned}
$$

Empirical logits (Cox \& Snell, 1981) are defined as

$$
\begin{gathered}
X=\ln [(x+0.5) /(146.5-x)] \\
Y=\ln [(y+0.5) /(25.5-y)]
\end{gathered}
$$

Values of $Y$ were used for plotting the relationship but were not used further in the analysis. Let $p$ be the probability of a species being found in a 1-km square of King's Lynn. Estimates of $p$ were obtained by logistic regression using the software package Minitab ${ }^{\mathrm{TM}}$ Release 13.20 , fitting parameters $a$ and $b$ to give the best fit to observed values of $y$ assuming the relationship

$$
\operatorname{logit}(p)=\ln [p /(1-p)]=a+b \mathrm{X}
$$

Note that the logit in equation (5) is the true logit and not the empirical logit used in equation (4).

Expected and observed frequencies were compared, both for individual species and for categories of species. For 
individual species, the significance of differences between observed and calculated numbers of occurrences was tested with an exact two-tailed test, assuming that occurrences in $1-\mathrm{km}$ squares were independent random events. For categories of species such as epiphytes, occurrences in 1-km squares were added across all species in the category and tested using the normal approximation to the Poisson distribution. Specifically, let $y$ be the observed number of occurrences and $\hat{y}$ be the estimated number using the model. Then the test statistic $z$ was

$$
z=(y-\hat{y}) / \hat{y}^{1 / 2}
$$

\section{RESULTS}

\section{Species richness}

In total, 151 bryophytes (134 mosses, 17 liverworts) were recorded in King's Lynn. This compares with 383 species found in the county of Norfolk since 1950 and 345 species found in the 146 squares (mostly $5-\mathrm{km}$ squares) used for regional comparison. The study area contained more species than any of the comparison squares in Cambridgeshire and Suffolk, and more than all but one of the $10-\mathrm{km}$ squares in the vicinity (Table 2). There was no evidence that the more urban $1-\mathrm{km}$ squares were speciespoor. The mean count of species for the 12 most urban squares was 43; that for the 5 most rural squares was 29 . The mean for the 8 mixed squares was 49 . Differences between counts for these categories were, however, not statistically significant.

\section{Distinctive nature}

In the regional analysis (Table 3) the fenland area of North Cambridgeshire differed markedly in mean Ellenberg values for light, moisture, reaction and fertility. Specifically, the fens appear to be lighter, drier, less acid and more fertile than the King's Lynn study area. These differences reflect the open, fertile countryside of the fens. Although there is wet ground along drains and in washes (land retained to receive floodwater), these habitats do not support enough bryophyte species to counteract the generally dry profile of drained fields and farm buildings. South Cambridgeshire was significantly less acid than the study area but otherwise similar. Cambridgeshire is perhaps the most uniformly calcareous county in Britain.

In the analysis of 1-km squares in King's Lynn (Table 4), differences between categories were nearly but not quite significant when the land cover categories (urban, mixed and rural) are considered. By contrast, all differences between the town centre and squares with ancient woodland were significant $(p<0.05)$, except that for light, which was nearly significant $(p<0.10)$. The difference for salt was also significant, but the elevated value in the centre was due to the presence of only four species, namely Amblystegium serpens $(S=2)$, Ceratodon purpureus $(S=1)$, Eurhynchium praelongum $(S=1)$ and Hennediella heimii $(S=5)$. The general relation between the combined Ellenberg values and species richness (Fig. 2) shows that squares in the town centre and completely rural squares were the most species-poor, while the three squares with ancient woodland were the most species-rich. There was also a strong

Table 2. Number of species in King's Lynn study area compared with other parts of eastern England; totals are for approximately 25 km ${ }^{2}$ except for the King's Lynn vicinity, which are for $100 \mathrm{~km}^{2}$.

\begin{tabular}{|c|c|c|c|c|c|}
\hline & King's Lynn study area & King's Lynn vicinity & Cambs $\mathrm{N}$ & Cambs S & Suffolk \\
\hline Mean number of species & 151 & 98 & 45 & 76 & 97 \\
\hline Number of units & 1 & 11 & 44 & 45 & 46 \\
\hline Area of units $\left(\mathrm{km}^{2}\right)$ & 25 & 100 & 25 & 25 & 24 \\
\hline \multicolumn{6}{|l|}{ Species richness } \\
\hline Maximum & & 189 & 86 & 116 & 142 \\
\hline 2nd & & 143 & 79 & 106 & 124 \\
\hline $3 \mathrm{rd}$ & & 131 & 73 & 102 & 119 \\
\hline 4 th & & 123 & 72 & 101 & 118 \\
\hline 5 th & & 105 & 70 & 96 & 116 \\
\hline
\end{tabular}

Table 3. Quantitative attributes of species in King's Lynn study area compared with those in other districts of eastern England. Values with an asterisk are significantly different from those for the King's Lynn study area.

\begin{tabular}{|c|c|c|c|c|c|c|}
\hline Variable & King's Lynn study area & King's Lynn vicinity & SD & Cambs $\mathrm{N}$ & Cambs S & Suffolk \\
\hline Number of units & 1 & 11 & & 44 & 45 & 46 \\
\hline Heavy metal & 0.5 & 0.6 & 0.08 & 0.6 & 0.5 & 0.6 \\
\hline Annuality & 12.6 & 10.2 & 5.17 & 14.1 & 10.3 & 11.1 \\
\hline Light & 5.9 & 6.2 & 0.26 & $6.5^{*}$ & 6.0 & 5.9 \\
\hline Moisture & 5.2 & 5.0 & 0.29 & $4.6^{*}$ & 4.8 & 5.0 \\
\hline Reaction & 5.7 & 6.0 & 0.34 & $6.5^{*}$ & $6.3^{*}$ & 5.9 \\
\hline Fertility & 4.3 & 4.3 & 0.26 & $4.9^{*}$ & 4.6 & 4.5 \\
\hline Salt & 0.1 & 0.1 & 0.03 & 0.1 & 0.1 & 0.1 \\
\hline
\end{tabular}

$* p<0.05$. 
Table 4. Number of squares and mean quantitative attributes of 1-km squares in the study area, grouped according to categories; NSpec is the mean number of species recorded per 1-km square; L, $M, R, N$ and $S$ are Ellenberg values.

\begin{tabular}{lrlllllll}
\hline Category & No. & NSpec & $\mathrm{L}$ & $\mathrm{M}$ & $\mathrm{R}$ & $\mathrm{N}$ & $\mathrm{S}$ & $\mathrm{L}+\mathrm{R}+\mathrm{N}-\mathrm{M}$ \\
\hline Urban & 12 & 42.8 & 6.2 & 4.6 & 6.3 & 4.8 & 0.2 & 12.6 \\
Mixed & 8 & 49.1 & 6.1 & 4.9 & 5.9 & 4.8 & 0.1 & 11.9 \\
Rural & 5 & 29.4 & 6.4 & 4.5 & 6.3 & 5.0 & 0.1 & 13.2 \\
Town centre & 1 & 28.0 & 6.5 & 4.3 & 6.7 & 5.0 & 0.3 & 13.9 \\
Ancient woods & 3 & 70.3 & 5.7 & 5.0 & 5.5 & 4.4 & 0.1 & 10.6 \\
\hline
\end{tabular}

negative correlation, -0.77 , between the number of species and the combined Ellenberg value. This reflects the fact that the commoner species tend to have high indicator values for light, reaction and fertility, and low moisture values.

\section{Toxitolerance}

There was no difference in the profiles of heavy metal tolerance between King's Lynn and comparison areas (Table 3). The mean heavy-metal tolerance of bryophytes in the $1-\mathrm{km}$ square at the town centre was 0.71 , almost exactly equal to the mean for the 24 other $1-\mathrm{km}$ squares in the town, also 0.71 .

\section{Life-forms and annuality}

Annuality varied markedly between areas (Table 5), with a mean standard deviation of 5.0 for variation between $25 \mathrm{~km}^{2}$ sample areas within regions. On this basis, North Cambridgeshire stands out again, its bryophytes being significantly more annual than those of the other areas ( $p=0.02$ for King's Lynn vicinity and $p<0.001$ for South Cambridgeshire). The study area, being based on a single sample was not significantly different from the other areas. The balance of life-forms was broadly similar for the study area and Suffolk, but again North Cambridgeshire was markedly different, having a preponderance of cushions and tufts (acrocarps) and a relatively low number of mats and wefts (pleurocarps). The rarer lifeforms were exceptionally poorly represented in North Cambridgeshire.

There was greater variation between the $1-\mathrm{km}$ squares of the study area. In particular, the five rural squares had high annuality, averaging 16.6. In one largely arable square (National Grid reference TF6222) in the northwest of the study area, annuality was 23.0, compared with 8.3 for the town centre and 8.0 for the three squares containing ancient woods. In this predominantly arable square, turfs were by a wide margin the dominant lifeform. Cushions and tufts were most frequent in the urban squares, especially the town centre. Mats and wefts, on the other hand, were especially frequent in the squares with ancient woodland.

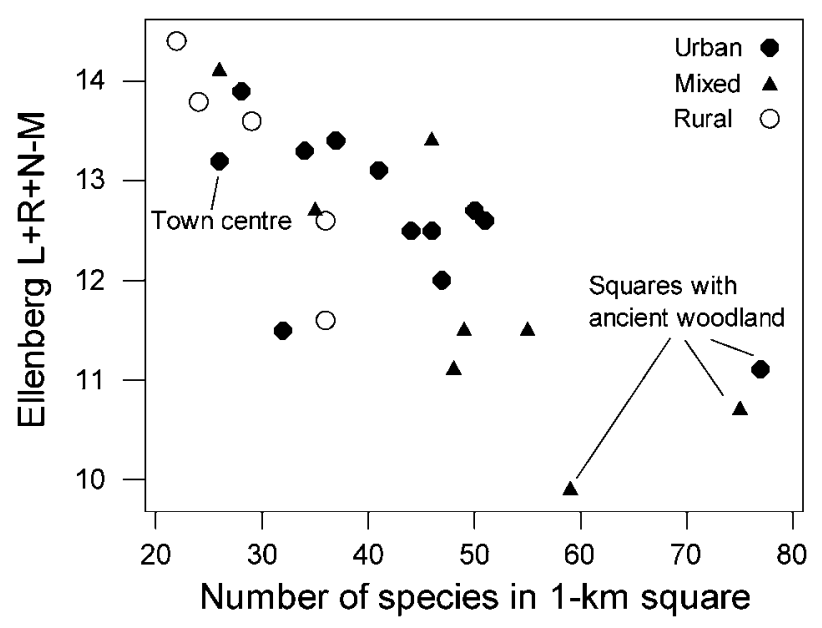

Figure 2. Combined Ellenberg values in relation to species richness in individual 1-km squares of King's Lynn study area; the urban square with ancient woodland contains just 2 ha of encapsulated woodland.

\section{Taxonomic bias}

The balance of bryophyte orders in the study area resembles that for Suffolk (Table 6). North Cambridgeshire is notable for its very low representation of leafy liverworts and Polytrichales. Within King's Lynn, Hypnales were high in ancient woods, Pottiales were relatively high in the town centre, and Bryales were relatively high in the rural squares. Dicranales, Orthotrichales, Polytrichales and leafy liverworts were low or missing in the town centre.

\section{Geographical bias}

On average, the species recorded in 1-km squares were more frequent in Great Britain than those in larger squares (Table 7). The species in King's Lynn town centre occurred

Table 5. Proportions (\%) of species in life forms in King's Lynn compared with other parts of eastern England; districts are as in Table 2.

\begin{tabular}{|c|c|c|c|c|c|}
\hline Area sampled & Annuality & $\begin{array}{l}\text { Cushion } \\
\& \text { tuft }\end{array}$ & Turf & $\begin{array}{l}\text { Mat } \\
\text { \& weft }\end{array}$ & Other \\
\hline \multicolumn{6}{|l|}{ (a) $25 \mathrm{~km}^{2}$ samples } \\
\hline Cambs N & 14.1 & 23.7 & 45.7 & 29.9 & 0.8 \\
\hline Cambs S & 10.3 & 19.7 & 41.8 & 34.9 & 3.5 \\
\hline King's Lynn study area & 12.6 & 17.2 & 43.7 & 33.8 & 5.3 \\
\hline King's Lynn vicinity & 10.2 & 18.3 & 42.9 & 35.1 & 3.7 \\
\hline $\begin{array}{l}\text { Suffolk } \\
\text { (b) } 1 \mathrm{~km}^{2} \text { samples }\end{array}$ & 11.1 & 18.3 & 42.0 & 35.0 & 4.6 \\
\hline King's Lynn all squares & 13.1 & 19.0 & 46.3 & 31.8 & 2.9 \\
\hline Urban & 10.3 & 22.4 & 41.5 & 35.5 & 0.6 \\
\hline Mixed & 15.1 & 17.4 & 47.7 & 32.5 & 2.4 \\
\hline Rural & 16.6 & 18.8 & 51.4 & 27.5 & 2.2 \\
\hline Town centre & 8.3 & 25.0 & 42.9 & 32.1 & 0.0 \\
\hline Ancient woods & 8.0 & 18.6 & 40.3 & 37.9 & 3.2 \\
\hline Rural square arable & 23.0 & 13.8 & 69.0 & 17.2 & 0.0 \\
\hline
\end{tabular}


Table 6. Bryophyte orders in King's Lynn compared with those in other parts of eastern England and in categories within the town.

\begin{tabular}{|c|c|c|c|c|c|c|c|c|c|c|}
\hline & Hypnales & Pottiales & Bryales & $\begin{array}{l}\text { Dicran- } \\
\text { ales }\end{array}$ & $\begin{array}{l}\text { Orthotri- } \\
\text { chales }\end{array}$ & $\begin{array}{l}\text { Polytri- } \\
\text { chales }\end{array}$ & $\begin{array}{l}\text { Grimm- } \\
\text { iales }\end{array}$ & $\begin{array}{l}\text { Other } \\
\text { mosses }\end{array}$ & $\begin{array}{c}\text { Leafy } \\
\text { liverworts }\end{array}$ & $\begin{array}{l}\text { Thalloid } \\
\text { liverworts }\end{array}$ \\
\hline \multicolumn{11}{|l|}{ (a) $25 \mathrm{~km}^{2}$ samples } \\
\hline Cambs $\mathrm{N}$ & 26.8 & 25.1 & 18.5 & 11.4 & 7.7 & 0.1 & 3.6 & 3.1 & 1.5 & 2.2 \\
\hline Cambs S & 30.3 & 23.8 & 14.5 & 10.7 & 7.2 & 0.6 & 2.7 & 2.3 & 3.8 & 4.0 \\
\hline King's Lynn study area & 26.5 & 19.2 & 16.6 & 12.6 & 5.3 & 4.6 & 1.3 & 2.6 & 6.0 & 5.3 \\
\hline King's Lynn vicinity & 28.8 & 20.6 & 15.5 & 12.2 & 4.4 & 1.9 & 3.3 & 3.6 & 4.7 & 5.0 \\
\hline $\begin{array}{l}\text { Suffolk } \\
\text { (b) } 1 \mathrm{~km}^{2} \text { samples }\end{array}$ & 29.4 & 19.7 & 16.4 & 11.8 & 6.0 & 2.3 & 2.3 & 2.6 & 5.2 & 4.3 \\
\hline King's Lynn all squares & 27.3 & 21.8 & 17.8 & 12.8 & 4.8 & 1.5 & 3.8 & 3.4 & 2.5 & 4.2 \\
\hline Urban & 28.4 & 24.9 & 16.3 & 9.7 & 4.6 & 1.3 & 4.6 & 3.2 & 2.7 & 4.3 \\
\hline Mixed & 26.8 & 18.4 & 17.1 & 17.4 & 4.5 & 1.9 & 2.9 & 2.9 & 3.9 & 4.1 \\
\hline Rural & 25.5 & 19.9 & 22.6 & 13.1 & 5.6 & 1.1 & 3.3 & 4.7 & 0.0 & 4.2 \\
\hline Town centre & 25.0 & 35.7 & 14.3 & 3.6 & 3.6 & 0.0 & 7.1 & 3.6 & 0.0 & 7.1 \\
\hline Ancient woods & 32.1 & 12.0 & 16.2 & 17.7 & 5.1 & 4.4 & 2.3 & 2.0 & 5.1 & 3.1 \\
\hline Rural square arable & 17.2 & 24.1 & 27.6 & 20.7 & 3.4 & 0.0 & 3.4 & 3.4 & 0.0 & 0.0 \\
\hline
\end{tabular}

on average in 1548 hectads, while bryophytes from $1-\mathrm{km}$ squares with ancient woods were on average in 1497 hectads. Among the larger sampling units, species from the King's Lynn study area were on average the least frequent (1204 hectads), while those in North Cambridgeshire were the most frequent (1431 hectads).

Climatic differences in the profiles of species were small. The mean climate profile of species in the town centre was almost identical to that of those in the rural squares. There is a suggestion that species of squares with ancient woods have a slightly wetter and cooler profile than those of the town centre or open country.

\section{King's Lynn flora in its regional context}

The commonest species in King's Lynn were Amblystegium serpens, Barbula convoluta, B. unguiculata, Brachythecium rutabulum, Bryum argenteum, B. bicolor, B. capillare, Ceratodon purpureus, Eurhynchium praelongum, Funaria hygrometrica, Grimmia pulvinata, Orthotrichum diaphanum, Rhynchostegium confertum and Tortula muralis. These species are all frequent in eastern England, and could be expected in almost any large village or farm. Indeed, the comparison between frequency in King's Lynn and frequency in East Anglia (Fig. 3) shows a stronger relationship between frequency in 5-km squares in East Anglia than that in 1-km squares of the study area.

The parameters $a$ and $b$ were estimated as $a=-1.283$, $b=0.983$. These values provide an exact fit to the mean species richness in 1-km squares, 42.1 species per square. However, they clearly refute the assumption that species occur in King's Lynn as a random subsample of those in the wider countryside. The assumption of randomness predicts that 178 species would be found in the survey, whereas in fact 151 were found. The difference is only just significant $(p=0.05)$ but the nature of the discrepancies (Table 8) makes it clear that there was clustering of some regionally uncommon species. At the $5 \%$ level of probability (two-tailed) there were 10 species that were significantly less frequent than would be expected, and 21 species that were significantly more frequent. Of these, the most extreme was Hennediella macrophylla, which had only an $18 \%$ chance of being found in the town at all, but which actually occurred in 6 squares.

Table 7. Geographical attributes of species in sampled squares; frequency is the mean for species present in the area of the number of hectads (10-km squares) from which they have been recorded in Great Britain; temperatures and annual precipitation are means for species present in the area of temperatures and precipitation in those hectads where they occur in the British Isles (including Ireland).

\begin{tabular}{|c|c|c|c|c|}
\hline Area sampled & Frequency in GB & January temperature $\left({ }^{\circ} \mathrm{C}\right)$ & July temperature $\left({ }^{\circ} \mathrm{C}\right)$ & Precipitation $(\mathrm{mm})$ \\
\hline \multicolumn{5}{|l|}{ (a) $25 \mathrm{~km}^{2}$ samples } \\
\hline Cambs $\mathrm{N}$ & 1431 & 3.8 & 15.2 & 978 \\
\hline Cambs S & 1340 & 3.8 & 15.1 & 991 \\
\hline King's Lynn study area & 1204 & 3.6 & 15.0 & 1013 \\
\hline King's Lynn vicinity & 1324 & 3.7 & 15.0 & 1025 \\
\hline $\begin{array}{l}\text { Suffolk } \\
\text { (b) } 1 \mathrm{~km}^{2} \text { samples }\end{array}$ & 1345 & 3.7 & 15.0 & 1010 \\
\hline King's Lynn all squares & 1518 & 3.8 & 15.1 & 996 \\
\hline Urban & 1502 & 3.8 & 15.1 & 993 \\
\hline Mixed & 1527 & 3.7 & 15.1 & 1002 \\
\hline Rural & 1544 & 3.8 & 15.1 & 993 \\
\hline Town centre & 1548 & 3.9 & 15.1 & 993 \\
\hline Ancient woods & 1497 & 3.6 & 15.0 & 1027 \\
\hline Rural square arable & 1489 & 3.9 & 15.2 & 971 \\
\hline
\end{tabular}




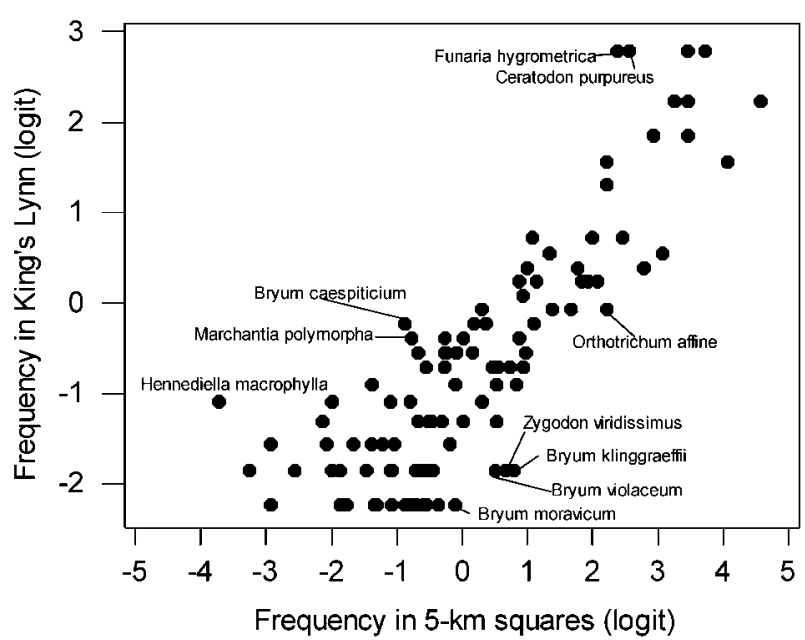

Figure 3. Frequency in King's Lynn $1-\mathrm{km}$ squares in relation to regional frequency in $5-\mathrm{km}$ squares.

\section{DISCUSSION}

\section{Statistical analysis}

Significance tests were based on the assumption that occurrences of species either in the town of King's Lynn or in the wider East Anglian region are random events. This assumption is undoubtedly false. Species occurrences are well known to be clustered at all scales, both because plants often colonize new sites close to existing ones and because suitable habitats tend to be clustered together in the countryside. The purpose of testing hypotheses against the random case is to establish whether there is even prima facie evidence of differences. For contributing to general understanding, comparisons between sites do not have to be significant to be worth considering. For example, King's Lynn has only a single town centre, so that differences between the town centre and other squares are unlikely to be significant in a sample of 25 .

The analysis to determine how far occurrences within King's Lynn reflect regional frequency was intended to be more rigorous. The logistic model was fitted formally, and tests for whether individual species or groups of species were significantly over- or under-represented were exact, given the assumption of random occurrence. Hennediella macrophylla clearly refutes the hypothesis of randomness. In the event, the number of species for which the assumption breaks down is not great, so that deviations ought to be capable of explanation. H. macrophylla is a neophyte in Britain, and is no doubt highly clustered because it is still spreading.

Table 8. Species rarer or more frequent in King's Lynn than would be expected from their regional frequency in 5-km squares; estimated numbers of occurrences in King's Lynn 1-km squares are derived from the regional frequency in 5-km squares.

\begin{tabular}{|c|c|c|c|c|}
\hline Species & No. of $5-\mathrm{km}$ squares & Estimated KL number & Actual KL number & Probability \\
\hline \multicolumn{5}{|l|}{ (a) Species rarer than expected } \\
\hline Didymodon sinuosus & 84 & 6.8 & 0 & 0.001 \\
\hline Rhynchostegiella tenella & 83 & 6.7 & 0 & 0.001 \\
\hline Didymodon luridus & 85 & 6.9 & 1 & 0.006 \\
\hline Bryum klinggraeffii & 101 & 9.5 & 3 & 0.009 \\
\hline Hypnum cupressiforme & 140 & 21.3 & 16 & 0.016 \\
\hline Zygodon viridissimus & 97 & 8.8 & 3 & 0.019 \\
\hline Syntrichia intermedia & 138 & 20.3 & 15 & 0.023 \\
\hline Orthotrichum affine & 132 & 17.7 & 12 & 0.027 \\
\hline Pseudocrossidium revolutum & 58 & 3.9 & 0 & 0.029 \\
\hline Bryum violaceum & 91 & 7.8 & 3 & 0.050 \\
\hline \multicolumn{5}{|c|}{ (b) Species more frequent than expected } \\
\hline Hennediella macrophylla & 3 & 0.2 & 6 & 0.000 \\
\hline Bryum caespiticium & 43 & 2.6 & 11 & 0.000 \\
\hline Marchantia polymorpha & 46 & 2.9 & 10 & 0.001 \\
\hline Plagiothecium succulentum & 17 & 0.9 & 6 & 0.001 \\
\hline Pseudotaxiphyllum elegans & 7 & 0.4 & 4 & 0.001 \\
\hline Tortula modica & 7 & 0.4 & 4 & 0.001 \\
\hline Aneura pinguis & 29 & 1.7 & 7 & 0.002 \\
\hline Fissidens exilis & 15 & 0.8 & 5 & 0.002 \\
\hline Brachythecium velutinum & 49 & 3.1 & 9 & 0.005 \\
\hline Dicranella cerviculata & 5 & 0.3 & 3 & 0.005 \\
\hline Funaria hygrometrica & 134 & 18.5 & 24 & 0.011 \\
\hline Didymodon tophaceus & 63 & 4.4 & 10 & 0.013 \\
\hline Physcomitrium pyriforme & 16 & 0.9 & 4 & 0.021 \\
\hline Ceratodon purpureus & 136 & 19.4 & 24 & 0.028 \\
\hline Hypnum resupinatum & 109 & 11.1 & 17 & 0.029 \\
\hline Atrichum undulatum & 53 & 3.5 & 8 & 0.032 \\
\hline Ditrichum cylindricum & 36 & 2.1 & 6 & 0.033 \\
\hline Tetraphis pellucida & 10 & 0.5 & 3 & 0.033 \\
\hline Fissidens incurvus & 84 & 6.8 & 12 & 0.042 \\
\hline Orthodontium lineare & 63 & 4.4 & 9 & 0.042 \\
\hline Mnium hornum & 64 & 4.5 & 9 & 0.048 \\
\hline
\end{tabular}




\section{Effects of scale}

One of the major challenges in comparing King's Lynn with the rest of the region was to eliminate the effects of scale. We found that larger recording units generally contain a relatively large proportion of uncommon species and have correspondingly lower mean Ellenberg values for reaction and fertility ( $R$ and $N$ ) and higher values for moisture $(M)$. Thus, it was not possible to compare frequencies in King's Lynn 1-km squares directly with regional frequency in, for example, $10-\mathrm{km}$ squares. It is well known that some species occur with local distributions more clumped than others (Kunin, 1998; Pearman, 1997), and that because of this, no uniform process of scaling down can be wholly reliable.

In spite of these difficulties, the relationship between regional frequency in 5-km squares and local frequency in $1-\mathrm{km}$ squares was remarkably good. Information on clumping of bryophytes is for the most part lacking, so that there is some inevitable uncertainty about comparisons between frequencies at the $1-\mathrm{km}$ and $5-\mathrm{km}$ square scales. It is encouraging that Hennediella macrophylla showed up as having a strongly clumped distribution. We believe our results are robust, but admit that additional sampling from other locations at $1-\mathrm{km}$ square resolution is needed to establish scaling relationships in bryophytes.

Species richness and composition

The King's Lynn flora is not impoverished. Indeed, it is exceptionally rich. Part of the high richness may be due to more intensive recording, in King's Lynn than in other parts of East Anglia. Some of the richness is due to the presence of ancient woodland within the town limits (Fig. 2). However, even without the ancient woods, the King's Lynn total is 127 species; the woods add only 24 extra species. The theory that urban areas are impoverished is refuted for King's Lynn. A similarly rich flora was found in Trento, northern Italy, where 136 species were recorded in an area of $4.5 \mathrm{~km}^{2}$ (Pokorny, Lara \& Mazimpaka, 2006). However, the 1-km square at the centre of King's Lynn had a poor flora, with only 28 species. Even the centre of London does not appear to be especially species-poor, with 78 species recorded in the Biological Records Centre database post 1969 in 10-km square TQ28; but this too contains encapsulated countryside.

It is clear from the regional analysis (Fig. 3) that for most species, the regional frequency is a good predictor of frequency in King's Lynn. Epiphytes were less frequent than would be expected by chance, but not significantly so. However, the 21 obligate epiphytes (in the sense of Bates et al. (1997), i.e. species with only living wood as a normal substrate according to BRYOATT (Hill et al., 2007) had a total occurrence summed over all squares of 23 , whereas 48.5 would be predicted. This discrepancy is highly significant and confirms the impression derived from Fig. 3 that epiphyte frequency in King's Lynn is low in relation to regional frequency. Hypnum cupressiforme, Orthotrichum affine and Zygodon viridissimus (only $O$. affine is an obligate epiphyte), had individually significant low frequency values (Table 8), but when the group is taken together, the effect is clear. Note that many of the trees commonly planted in urban areas, such as London plane Platanus $\times$ hispanica, conifers and ornamental cherries (Prunus spp.) are typically poor in obligate epiphytes, even when planted in the country.

Of the other species that were significantly rare or absent, Didymodon luridus, D. sinuosus, Pseudocrossidium revolutum and Rhynchostegiella tenella are calcicoles often found on sheltered masonry. Their absence from King's Lynn reflects the fact the local building stone is non-calcareous, with limestone used only in a few old churches and churchyards, which have been tidied-up to the detriment of bryophytes. Likewise, Syntrichia intermedia is a calcicole of dry roofs and masonry. The relative scarcity of Bryum klinggraeffii and $B$. violaceum is because these two ephemerals are most characteristic of arable fields, a habitat poorly represented in urban areas and in the King's Lynn study area.

Twenty-one species were significantly more common than would be predicted from regional frequency (Table 8). Four of these, Bryum caespiticium, Ceratodon purpureus, Funaria hygrometrica and Marchantia polymorpha are indeed distinctively urban; all occur in the centre of King's Lynn. Nine of the remainder are calcifuges, which in East Anglia are either rare (Dicranella cerviculata, Pseudotaxiphyllum elegans, Tetraphis pellucida) or occasional (Atrichum undulatum, Ditrichum cylindricum, Fissidens exilis, Mnium hornum, Orthodontium lineare, Plagiothecium succulentum). Hennediella macrophylla is presumably a fairly new introduction. Aneura pinguis, Didymodon tophaceus, Fissidens incurvus, Tortula modica and Physcomitrium pyriforme are found either on clay banks of the numerous dykes that cut through the town or on mud banked on their sides when they are cleaned out. Hypnum resupinatum may well have been under-recorded in the region because it is doubtfully distinct from $H$. cupressiforme. We have no explanation of why Brachythecium velutinum should be especially frequent in the town.

The representation of taxonomic orders generally follows the regional trend. Of the larger orders, Sphagnales and Orthotrichales are significantly under-represented, reflecting the effects of drainage and the lack of obligate epiphytes, and Dicranales are over-represented in spite of being under-represented in the town centre.

\section{Ecological attributes of the flora}

Although the flora of King's Lynn closely reflects that of the East Anglian region, there are some distinctive features. The low occurrence of obligate epiphytes, which are less than half as frequent as would be expected, is notable. Another notable feature is the high number of calcifuges, 
with 279 occurrences of species with Ellenberg R less than 6 , where 229 would be expected $(p=0.001)$. There is a corresponding deficit of calcicoles, with 494 occurrences of species with R greater than 7 where 542 would be expected $(p=0.05)$. This reflects the local geology and soils.

When the flora was analysed by substrate preference (from BRYOATT; Hill et al., 2007), species characteristic of soil, peat, gravel and sand, and dead wood were significantly more frequent than would be expected by chance. The discrepancies for substrates other than peat were not very large, being in the range $11-14 \%$. They may conceivably be due to comparing $1-\mathrm{km}$ squares with $5-\mathrm{km}$ squares. We have no way of knowing this without an intensively-sampled set of rural 1-km squares for comparison. The discrepancy for peat was, however, 40\% (140 occurrences of peat-substrate species when 100 would be expected). Peat is locally scarce as a substrate, and the high occurrence of species in this group reflects the fact that they can also occur on the acid sandy soils with deep leaf litter to the north of the town.

There was also a nearly-significant $(p=0.055)$ difference between the number of occurrences of the weft life-form and the number expected (59 observed, 76 expected). Weft formers tend to be large mosses and liverworts of longestablished woodland and grassland, and although Calliergonella cuspidata and Rhytidiadelphus squarrosus are common enough in the urban environment, others such as Cirriphyllum piliferum, Eurhynchium striatum, Homalothecium lutescens, Pleurozium schreberi, Rhytidiadelphus triquetrus, Scleropodium purum and Thuidium tamariscinum are distinctly under-represented in King's Lynn.

\section{ConClusions}

The hypotheses of impoverishment, toxitolerance and thermophilic tendency are not true for King's Lynn. In general, the King's Lynn flora is not distinctive, with frequencies in $1-\mathrm{km}$ squares being well predicted by regional frequency in East Anglia. However, Bryum caespiticium, Ceratodon purpureus, Funaria hygrometrica and Marchantia polymorpha appear to be commoner in urban King's Lynn than their admittedly widespread occurrence elsewhere would indicate. In the other direction, obligate epiphytes and weft-forming bryophytes of woodland were less frequent in King's Lynn than would be expected from their regional frequency. With this minor proviso, there was no evidence that colonists were at a special advantage. In the town centre, Pottiales were overrepresented, whereas Dicranales and Orthotrichales were under-represented. Calcifuge species, including Polytrichales, were more frequent in King's Lynn than in the East Anglian region, reflecting the local geology and soils.

While some of these results are specific to King's Lynn, others are clearly more general. To understand the broader picture, we need comparable studies both from large cities and from some rural areas.

\section{ACKNOWLEDGEMENTS}

Friends, colleagues, and total strangers have allowed access to their land and gardens, the latter largely through the good offices of Frances Schumann. Richard Fisk and Chris Preston supplied us with data regarding the floras of Suffolk and Cambridge; Rosa Lo Giudice, Patxi Heras, Jan Żarnowiec and Ewa Fudali supplied reprints. Ewa has been particularly helpful in response to numerous queries about her work on urban bryophytes. We thank them all. We are also grateful to Peter Rothery (Monks Wood) for advice on logistic regression, and again to Chris Preston for commenting on an earlier draft.

\section{Taxonomic Additions And Changes: Nil.}

\section{REFERENCES}

Adams KJ, Preston CD. 1992. Evidence for the effects of atmospheric pollution on bryophytes from national and local recording. In: Harding PT, ed. Biological recording of changes in British wildlife. London: HMSO, 31-43.

Ballesteros Segura T, Ron ME. 1985. Contribución al estudio de la flora briológica de la ciudad de Toledo. Anales del Jardín Botánico de Madrid 42: 87-91.

Barrow EM, Hulme M, Jiang T. 1993. A 1961-90 baseline climatology and future climate change scenarios for Great Britain and Europe. Part I: 1961-90 Great Britain baseline climatology. Norwich: Climatic Research Unit.

Bates JW, Bell JNB, Farmer AM. 1990. Epiphyte recolonization of oaks along a gradient of air pollution in south-east England, 19791990. Environmental Pollution 68: 81-99.

Bates JW, Proctor MCF, Preston CD, Hodgetts NG, Perry AR. 1997. Occurrence of epiphytic bryophytes in a 'tetrad' transect across southern Britain 1. Geographical trends in abundance and evidence of recent change. Journal of Bryology 19: 685-714.

Beckett G, Bull A, Stevenson R. 1999. A flora of Norfolk: Privately published by Gillian Beckett.

Burton MAS. 1990. Terrestrial and aquatic bryophytes as monitors of environmental contaminants in urban and industrial habitats. Botanical Journal of the Linnean Society 104: 267-280.

Carcano L. 1989. Moss inventory of the urban area of Rome. BraunBlanquetia 3: 147-150.

Cortini Pedrotti C. 1989. La flore bryologique de la ville de Camerino (Italie centrale). Braun-Blanquetia 3: 241-246.

Cox DR, Snell EJ. 1981. Analysis of binary data. 2 edn. London: Chapman \& Hall.

Fudali E. 1994. Species diversity and spatial distribution of bryophytes in urban areas - a case study of the city of Szczecin. Fragmenta Floristica et Geobotanica 39: 563-570.

Fudali E. 1996. Distribution of bryophytes in various urban-use complexes of Szczecin (NW Poland). Fragmenta Floristica et Geobotanica 41: 717-745.

Fudali E. 1998. Investigations of bryophytes in Polish towns - a review of the bryological research and data. Fragmenta Floristica et Geobotanica 43: 77-101.

Fudali E. 2000. Some open questions of the bryophytes of urban areas and their response to urbanization's impact. Perspectives in Environmental Sciences 2: 14-18.

Fuller RM, Groom GB, Jones AR. 1994. The Land Cover Map of Great Britain: an automated classification of Landsat Thematic Mapper 
data. Photogrammetric Engineering and Remote Sensing 60: 553562.

Gilbert OL. 1968. Bryophytes as indicators of air pollution in the Tyne valley. New Phytologist 67: 15-30.

Gilbert OL. 1971. Urban bryophyte communities in north-east England. Transactions of the British Bryological Society 6: 306-316.

Gilbert OL. 1989. The ecology of urban habitats. London: Chapman \& Hall.

Heras P, Soria A. 1990. Musgos y hepáticas urbanos de la ciudad de Vitoria-Gasteiz. Sociedad de Estudios Vascos - Eusko Ikaskuntza, Cuadernos de Sección, Ciencias Naturales 7: 75-116.

Hill MO, Preston CD, Bosanquet SDS, Roy DB. 2007. BRYOATT: attributes of British and Irish mosses, liverworts and hornworts. Huntingdon: Centre for Ecology \& Hydrology.

Hohenwallner D, Zechmeister HG. 2001. Factors influencing bryophyte species richness and populations in urban environments: a case study. Nova Hedwigia 73: 87-96.

Kunin WE. 1998. Extrapolating species abundance across spatial scales. Science 281: 1513-1515.

Lara F, López C, Mazimpaka V. 1991. Ecología de los briófitos urbanos en la ciudad de Segovia (España). Cryptogamie, BryologieLichénologie 12: 425-439.

Lo Giudice R. 1992. Contributo alla conoscenza della brioflora urbana di Catania. Quaderni di Botanica Ambientale e Applicata 3: $3-10$.
Lo Giudice R, Mazimpaka V, Lara F. 1997. The urban bryophyte flora of the city of Enna (Sicily, Italy). Nova Hedwigia 64: 249-265.

Payne RM. 1995. The flora of King's Lynn. Transactions of the Norfolk and Norwich Naturalists' Society 30: 317-342.

Pearman D. 1997. Towards a new definition of rare and scarce plants. Watsonia 21: 225-245.

Petch CP, Swann EL. 1968. Flora of Norfolk. Norwich: Jarrold \& Sons.

Pokorny L, Lara F, Mazimpaka V. 2006. The bryophyte flora of the city of Trento (North Italy). Cryptogamie, Bryologie 27: 265-284.

Ron E, Mazimpaka V, Vicente J, Granzow de la Cerda I. 1987. Urban bryophytes in Spanish towns. Symposia Biologica Hungarica 35: $727-753$.

Schaepe A. 1986. Veränderungen der Moosflora von Berlin (West). Berlin/Stuttgart: J. Cramer.

Soria A, Ron ME. 1995. Aportaciones al conocimiento de la brioflora urbana española. Cryptogamie, Bryologie-Lichénologie 16: 285-299.

Swann EL. 1975. Supplement to the Flora of Norfolk. Norwich: F. Crowe \& Sons.

Swann EL. 1982. Norfolk bryophytes today. Journal of Bryology 12: 77-112.

UNESCO. 1973. Ecological effects of utilisation in urban and industrial systems. Expert Panel Project II, MAB report No. 13. Paris: UNESCO.

Vanderpoorten A. 1997. A bryological survey of the Brussels Capital Region (Belgium). Scripta Botanica Belgica 14: 1-83.

C. Robin Stevenson, 111, Wootton Road, King's Lynn, Norfolk PE30 4DJ, U.K. E-mail: crs1942@tiscali.co.uk

Mark O. HILl, Centre for Ecology and Hydrology, Monks Wood, Abbots Ripton, Huntingdon PE28 2LS, U.K. E-mail: moh@ceh.ac.uk 